\title{
Genotype Distribution of Hepatitis C Virus and Demographic Features of The Patients in The Province of Karabük
}

\author{
Karabük Ilinde Hepatit C Virüsünün Genotip Dağılımı ve Olguların Demografik Özellikleri
}

\author{
(1) Cüneyt Kuru1, (1) Aziz Ahmad Hamidi2
}

${ }^{1}$ Karabük University, Karabük Training and Research Hospital, Clinic of Medical Microbiology, Karabük, Turkey

${ }^{2}$ Karabük University Karabük Training and Research Hospital, Clinic of Infectious Diseases and Clinical Microbiology, Karabük, Turkey

\begin{abstract}
Objectives: It was aimed to determine the distribution of hepatitis $\mathrm{C}$ virus (HCV) genotypes among patients who had HCV infection, and to identify the demographic characteristics of these patients. Materials and Methods: Adult patients who underwent HCV genotyping between January 2016 and December 2019 in the microbiological laboratory of our hospital were included in the research. The age and gender of the patients were investigated retrospectively from the hospital registry.

Results: $63 \%$ of the 169 patients who were included in the study were female and the mean age was $63.4 \pm 16.1$. It was found out that of the patients, $85.8 \%$ were with genotype $1 \mathrm{~b}, 4.2 \%$ with genotype 1 a and $0.62 \%$ with genotype 2 , while $3 \%$ of them had genotype 3 and $11 \%$ of them had genotype 4 . It was determined that the mean age $(62.2 \pm 14.6)$ and rate of female gender of patients who had genotype 1 was significantly higher than other patients. Whereas genotype $1 \mathrm{~b}$ did not decline over the years, a slight increase was determined in genotype 4.

Conclusion: It was found out that genotype $1 \mathrm{~b}$, was to be the most frequent genotype. The fact that most of the patients were female as well as they were elderly is epidemiologically remarkable.

Keywords: Genotype, hepatitis C virus, viral infection
\end{abstract}

ÖZ

Amaç: Hepatit C virüsü (HCV) infeksiyonu olan olgularda HCV genotip dağııııını belirlenmesi ve hastaların demografik bilgilerin saptanması amaçlanmıştır.

Gereç ve Yöntemler: Hastanemiz mikrobiyoloji laboratuvarında Ocak 2016-Aralık 2019 tarihleri arasında HCV genotiplendirmesi yapılan erişkin hastalar çalışmaya dahil edilmiştir. Olguların yaş ve cinsiyeti geriye dönük olarak hastane kayıtlarından incelenmiştir. Bulgular: Çalışmaya alınan 169 olgunun \%63'ü kadın olup yaş ortalaması $63,4 \pm 16,1$ idi. Olguların $\% 85,8$ 'inde genotip1b, $\% 4,2$ 'inde genotip 1a, \%0,6 2'inde genotip 2, \%3'ünde genotip 3 ve \%11'inde genotip 4 sapanmıştır. Genotip 1 olgularında yaş ortalaması $(62,2 \pm 14,6)$ ve kadın cinsiyeti genotip 1 dışı olgulara göre belirgin olarak yüksek bulunmuştur. Yıllar içinde genotip $1 \mathrm{~b}$ 'de azalma saptanmazken genotip 4'te hafif bir artış belirlenmiştir. Sonuç: Genotip 1b en yaygın genotip olarak saptanmıştır. Hastaların ileri yaşta olup kadın cinsiyetinin daha fazla olması epidemiyolojik açıdan dikkati çekmektedir.

Anahtar Kelimeler: Genotip, hepatit C virüsü, viral infeksiyon 


\section{Introduction}

Hepatitis $\mathrm{C}$ virus (HCV) is a single-stranded RNA virus from the Flaviviridae virus family and is a crucial public health problem across the world. It is the cause of chronic liver disease, and cirrhosis as well as hepatocellular carcinoma $(1,2)$. It is estimated that around one million people have been infected with HCV in Turkey (3). Hitherto, 7 distinct genotypes and over 90 sub-types of HCV have been identified. It has been found that specific genotypes have prevalence in various geographical regions of the world. While genotype $1(46.2 \%)$ is the most prevalent genotype across the world, it is followed by genotype $3,2,4$, and 6 , respectively Whereas, genotype $5(0.8 \%)$ is the least prevalent HCV genotype. Genotype 1 is the most prevalent HCV genotype in Turkey $(4,5,6)$. It was found in the researches, which was performed in our country, that majority of the patients had genotype/sub-type1b, whereas few of them had genotype/sub-type 1a $(7,8)$.

Knowing the distribution of HCV genotype is crucial for determining the epidemiological characteristics of infection, as well as for the selection of direct-acting antiviral therapies. Direct-acting antiviral agents have specific efficiencies in different genotypes. Hence, treatment guidelines recommend treatment regimens and duration of treatment based on HCV genotypes $(9,10)$.

In this study, it was intended to find out the genotype distribution among patients who had chronic HCV infection in our hospital and to investigate the demographic findings of these patients.

\section{Materials and Methods}

$\mathrm{HCV}$ genotyping was conducted among patients whose HCVRNA was detected as positive from serum samples that were tested in the Microbiology Laboratory of Karabük University, Training and Research Hospital between January 2016 and December 2019. Magnesia Viral DNA/RNA Extraction Kit EP and Magnesia16 Nucleic Acid Extraction Instrument (Anatolia Geneworks) were utilized for the extraction of viral RNA. Subsequently, extracted samples were studied following the instructions of the manufacturer by using Bosphore HCV Genotyping Kit v3 on Montania 4896 Real-Time PCR device (Anatolia Geneworks), and genotyping was accomplished.

The data including age, gender, and nationality of the patients were obtained from the registry and database system of the hospital. Restudied samples and patients who were under 18 years old were excluded from the research.

Thereafter, the distribution of HCV genotypes was analyzed regarding the age, gender, and years. The patients were subclassified as 18-25, 26-35, 36-45, 46-55, 56-65, and over 65 based on their age range.

\section{Statistical Analysis}

The software of Statistical Package (SPSS Inc.; Chicago, IL, USA) 15.0 Windows was used for the statistical analysis of data. Chi-square test was used for descriptive statistical variables that include the mean values, and standard deviation as well as for the categorical variables, while the Student t-test was used for normally distributed variables. Alpha significance level was considered as $<0.05$.

\section{Results}

HCV-genotyping of 169 patients was performed with the blood samples that had been given to the microbiology laboratory of our hospital throughout the study. The mean age of the patients was $63.4 \pm 16.1$, while 107 (63\%) of them were female, and 62 $(37 \%)$ were male. The rate of female patients was found to be significantly higher $(\mathrm{p}<0.05)$. Genotype $1 \mathrm{~b}$ was detected in 145 patients $(85.8 \%)$. Also, it was determined that $62.7 \%$ (106) of the patients were over 65 years old. In addition to that, 98\% (104) of these patients had genotype $1 \mathrm{~b}$. Besides, of these patients who had genotype 1b 66\% (70) were female (Table 1). Genotype 3 was detected in two female patients who had the nationality of Afghanistan. Apart from these two female patients, all of the patients were citizens of the Republic of Turkey.

A moderate rise has been determined in the number of genotype 4 per year in our hospital. However, genotype $1 \mathrm{~b}$ was found to be significantly higher in all years (Table 2).

Upon comparing the patients with and without genotype 1, it was demonstrated that the mean age of patients with genotype 1 was $62.2 \pm 14.6$, while the mean age of all other patients was $50.8 \pm 18.7$. The mean age was significantly higher in genotype 1 patients $(p<0.001)$. The rate of women among patients with genotype 1 was 68\% (103), while the rate of women among patients who had not genotype 1 was 30\% (5). Thus, it was identified that the female ratio among patients who had genotype 1 was significantly higher $(p<0.002)$.

\begin{tabular}{|c|c|c|c|c|c|c|c|c|c|c|c|c|c|c|c|c|c|c|}
\hline \multirow[t]{2}{*}{ Age } & \multicolumn{2}{|c|}{ Female } & \multicolumn{2}{|c|}{ Male } & \multicolumn{2}{|l|}{ Total } & \multicolumn{2}{|c|}{ G.1a } & \multicolumn{2}{|l|}{ G.1b } & \multicolumn{2}{|l|}{ G.1 } & \multicolumn{2}{|c|}{ G.2 } & \multicolumn{2}{|l|}{ G.3 } & \multicolumn{2}{|c|}{ G.4 } \\
\hline & $n$ & $\%$ & $n$ & $\%$ & $\mathrm{~N}$ & $\%$ & $\mathrm{~N}$ & $\%$ & $n$ & $\%$ & $n$ & $\%$ & $n$ & $\%$ & $n$ & $\%$ & $\mathrm{n}$ & $\%$ \\
\hline $18-25$ & - & - & 5 & & 5 & 3 & 3 & 43 & - & - & 3 & 2 & - & - & 1 & 10 & 1 & 17 \\
\hline $26-35$ & 1 & 11 & 8 & 89 & 9 & 5 & 3 & 43 & - & - & 3 & 2 & - & - & 4 & 40 & 2 & 33 \\
\hline $36-45$ & 5 & 83 & 1 & 17 & 6 & 4 & - & - & 4 & 2 & 4 & 3 & - & - & 2 & 20 & - & - \\
\hline $46-55$ & 5 & 83 & 1 & 17 & 6 & 4 & - & - & 4 & 2 & 4 & 3 & - & - & 2 & 20 & - & - \\
\hline $56-65$ & 26 & 70 & 11 & 30 & 37 & 21 & 1 & 14 & 33 & 23 & 34 & 22 & - & - & 1 & 10 & 2 & 33 \\
\hline$>65$ & 70 & 66 & 36 & 34 & 106 & 63 & - & - & 104 & 73 & 104 & 68 & 1 & 100 & - & - & 1 & 17 \\
\hline Total & 107 & 63 & 62 & 37 & 169 & 100 & 7 & 100 & 145 & 100 & 152 & 100 & 1 & 100 & 10 & 100 & 6 & 100 \\
\hline
\end{tabular}




\begin{tabular}{|l|l|l|l|l|l|l|l|}
\hline Table 2. The distribution of HCV genotypes per year \\
\hline Year & $\begin{array}{l}\text { Genotip 1a } \\
\mathbf{n}(\%)\end{array}$ & $\begin{array}{l}\text { Genotip 1b } \\
\mathbf{n}(\%)\end{array}$ & $\begin{array}{l}\text { Genotip 1 } \\
\mathbf{n}(\%)\end{array}$ & $\begin{array}{l}\text { Genotip 2 } \\
(\%)\end{array}$ & Genotip 3 n (\%) & Genotip 4 n (\%) & Total \\
\hline 2016 & - & $28(100)$ & $28(100)$ & - & - & - & 28 \\
\hline 2017 & $1(1.5)$ & $57(90.5)$ & $58(92.0)$ & $1(1.5)$ & $1(1.5)$ & $3(5.0)$ & 63 \\
\hline 2018 & $5(13.2)$ & $26(68.3)$ & $31(81.5)$ & - & $4(10.5)$ & $3(8.0)$ & 38 \\
\hline 2019 & $1(2.5)$ & $34(85.0)$ & $35(87.5)$ & - & - & $5(12.5)$ & 40 \\
\hline Total & $7(4.2)$ & $145(85.7)$ & $152(90)$ & $1(0.6)$ & $5(3.0)$ & $11(6.5)$ & 169 \\
\hline HCV: Hepatitis C virus & & & & & \\
\hline
\end{tabular}

\section{Discussion}

It has been determined that the genotype 1 was the most prevalent (90\%) among the population of the research over four years. Genotype 1 is the most common genotype across the world $(5,11)$. Similar to our findings, it was found out in the researches, which were performed previously in Turkey, that the genotype 1 was the most frequent genotype $(8,12,13,14)$. In recent years, the rate of genotype 1 (79.8\%) was found to be lower in the research, which was conducted in Izmir by Kaya et al. (12), compared to our results, while this rate was found to be 89.5\% in the research, which was performed in Aydın by Tiryaki et al. (8), that was analogous to our findings. The mean age of patients in previous studies conducted in Turkey was 41-56, and it was lower compared to our findings $(15,16,17,18)$. In the study, which was performed by Kaya et al. (12), $30.7 \%$ of the patients were identified as 65 years and over. Unlike the study of Kaya et al. (12), the mean age of the patients was higher (63.4) in our study, while $60.7 \%$ of the patients were over 65 years old. Genotype $1 \mathrm{~b}$ (98\%) was determined to be the most dominant genotype among the patients over 65 years old. In another study conducted by Altuglu et al. (19), iatrogenic risks such as dental procedures and surgeries were found to be the most prevalent risk factors for $\mathrm{HCV}$. Determination of the higher mean age in our research compared to previous studies points out to a decline in the incidence rate of new infections among younger people. Hence, this finding reveals that measures, which diminish iatrogenic contamination, such as safe blood transfusion, are efficient. No variation was detected between the ratios of males and females in studies, by which risk factors for HCV infection were investigated $(19,20)$. However, the number of female patients was found significantly (63\%) higher in our study. Moreover, when compared with patients who had not genotype 1, it was determined that the rate of elderly and female patients was significantly higher among our patients with genotype 1 .

Upon examining the distribution of genotypes per year, it was found out that there was a moderate increase in genotype 4, while the rate of genotype $1 \mathrm{~b}$ was higher among our patients in all years. It was revealed in the study of Tiryaki et al. (8) that 11 patients were foreign nationals, and genotype 4 was most prevalent among Syrian patients. Apart from 2 Afghan patients (genotype 3), all of the patients who had been included in our research were citizens of the Republic of Turkey and had lived in the province of Karabük.

\section{Study Limitations}

Our study does not provide adequate data related to risk factors and modes of transmission for patients since the study investigates records of hospital retrospectively. Thus, it is unable to clarify why the female gender is dominant.

\section{Conclusion}

It has been found out that the female gender was most common among $\mathrm{HCV}$ cases in our province, genotype $1 \mathrm{~b}$ was the most prevalent genotype, and our patients had applied to hospital at advanced ages. We are of the opinion that our research might be a guideline in terms of epidemiological knowledge and for the selection of treatment.

\section{Ethics}

Ethics Committee Approval: The research was performed following the approval, which is numbered with 77192459-050.99E.21430 and dated to 11.06.2020, of Karabük University Noninvasive Clinical Research Ethics Committee.

Informed Consent: It wasn't obtained.

Peer-review: Externally peer-reviewed.

\section{Authorship Contributions}

Concept: C.K., A.A.H, Design: A.A.H, Data Collection or Processing: C.K., Analysis: C.K., A.A.H, Literature Search: C.K., A.A.H, Writing: C.K., A.A.H.

Conflict of Interest: All authors declare to have no conflict of interest.

Financial Disclosure: The authors declare that this study has not received any financial support.

\section{References}

1. Simmonds P, Becher P, Bukh J, Gould EA, Meyers G, Monath T, Muerhoff S, Pletnev A, Rico-Hesse R, Smith DB, Stapleton JT, Ictv Report Consortium. ICTV Virus Taxonomy Profile: Flaviviridae. J Gen Virol. 2017:98:2-3.

2. Wang LS, D'Souza LS, Jacobson IM. Hepatitis C-A clinical review. J Med Virol. 2016;88:1844-1855.

3. Tozun N, Ozdogan O, Cakaloglu Y, Idilman R, Karasu Z, Akarca U, Kaymakoglu S, Ergonul O. Seroprevalence of hepatitis B and C virus infections and risk factors in Turkey: a fieldwork TURHEP study. Clin Microbiol Infect. 2015;21:1020-1026.

4. Smith DB, Bukh J, Kuiken C, Muerhoff AS, Rice CM, Stapleton JT, Simmonds P. Expanded classification of hepatitis $C$ virus into 7 genotypes and 67 subtypes: updated criteria and genotype assignment web resource. Hepatology. 2014;59:318-327.

5. Messina JP, Humphreys I, Flaxman A, Brown A, Cooke GS, Pybus OG, Barnes E. Global distribution and prevalence of hepatitis C virus genotypes. Hepatology. 2015;61:77-87. 
6. Ramia S, Eid-Fares J. Distribution of hepatitis $C$ virus genotypes in the Middle East. Int J Infect Dis. 2006;10:272-277.

7. Bozdayi AM, Aslan N, Bozdayi G, Turkyilmaz AR, Sengezer T, Wend U, Erkan O, Aydemir F, Zakirhodjaev S, Orucov S, Bozkaya H, Gerlich W, Karayalçin S, Yurdaydin C, Uzunalimoğlu O. Molecular epidemiology of hepatitis B, C and D viruses in Turkish patients. Arch Virol. 2004;149:2115-2129.

8. Tiryaki Y, Cetin Duran A, Ozcolpan OO. Distribution of Hepatitis C Virus Genotypes in Aydın Province. Viral Hepat J. 2018;24:70-74.

9. Panel A-IHG. Hepatitis C Guidance 2018 Update: AASLD-IDSA Recommendations for Testing, Managing, and Treating Hepatitis C Virus Infection. Clin Infect Dis. 2018;67:1477-1492.

10. Omata M, Kanda T, Wei L, Yu ML, Chuang WL, Ibrahim A, Lesmana CRA, Sollano J, Kumar M, Jindal A, Sharma BC, Hamid SS, Dokmeci AK, Mahtab M-A, McCaughan GW, Wasim J Crawford DHG, Kao J-O, Yokosuka O, Lau GKK, Sarin SK. APASL consensus statements and recommendation on treatment of hepatitis C. Hepatol Int. 2016;10:702-726

11. Ansaldi F, Orsi A, Sticchi L, Bruzzone B, Icardi G. Hepatitis C virus in the new era: perspectives in epidemiology, prevention, diagnostics and predictors of response to therapy. World $j$ Gastroenterol. 2014;20:9633-9652.

12. Kaya S, Afsar I, Sener AG, Sayıner A. Evaluation of Hepatitis C Virus Genotype Results in Izmir Atatürk Training and Research Hospital. Viral Hepat J. 2019;25:59-61.

13. Tuzuner U, Gulcen BS, Ozdemir M, Feyzioglu B, Baykan M Seven-year Genotype Distribution Among Hepatitis C Patients in a City in the Central Anatolia Region of Turkey Viral Hepat J. 2018;24:12-17
14. Saglik I, Mutlu D, Ongut G, Inan D, Ogunc D, Can Sarinoglu R, Özhak Baysan B, Gültekin M, Çolak D. [Distribution of hepatitis C virus genotypes among patients with chronic hepatitis $\mathrm{C}$ infection in Akdeniz University Hospital, Antalya, Turkey: a five-year evaluation]. Mikrobiyol Bul. 2014;48:429-437.

15. Harman R, Gunal O, Ozger S. Hepatitis C virus genotype distribution in patients with chronic hepatitis C in Gaziantep province Klimik Derg. 2017;30:68-70.

16. Ozer Balin S, Sagmak Tartar A, Akbulut A, Ascl Toraman Z. Distribution of Hepatitis C Virus Genotype in Elazığ and the Relantionship Between HCV RNA and Serum Alanine Aminotransferase Levels With Genotype. Ankem Derg. 2017;3:4852.

17. Caliskan A, Kirisci O, Ozkaya E, Ozden S, Tumer S, Caglar S, Ates Guler S, Senol H. Distribution and predominance of genotype 3 in hepatitis $\mathrm{C}$ virus carriers in the province of kahramanmaras, Turkey. Hepat Mon. 2015;15:e25142.

18. Altuglu I, Soyler I, Ozacar T, Erensoy S. Distribution of hepatitis C virus genotypes in patients with chronic hepatitis $C$ infection in Western Turkey. Int J Infect Dis. 2008;12:239-244.

19. Altuglu I, Sertoz R, Aksoy A, Gursel D, Tuzuner U, Gunsar F. Possible transmission risks and genotype distribution of hepatitis C virus infection in Western Turkey. Turk J Gastroenterol. 2013;24:349-355.

20. Iliaz R, Yuce T, Torun S, Cavus B, Gulluoglu M, Bozaci M, Karaca C, Akyuz F, Demir K, Besisik F, Kaymakoglu S. Changing epidemiology of chronic hepatitis C: patients are older and at a more advanced stage at the time of diagnosis. Eur $\mathrm{J}$ Gastroenterol Hepatol. 2019;31:1247-1249. 